\title{
Preventing Drug Addiction
}

\author{
Marvin Druger* \\ Professor emeritus, Biology and Science Education, USA
}

*Corresponding author: Marvin Druger, Professor emeritus, Biology and Science Education, 315 Life Sciences Complex, Syracuse, NY 13244, USA

Submission: 啡 March 28, 2018; Published: 眥 April 18, 2018

\section{Opinion}

I was a bit surprised when I received a request to write this article for the journal. After all, I don't know much about forensics or addiction. I was a faculty member in biology and science education at Syracuse University for 47 years and I retired in 2009. I am now a professor emeritus. I am still involved in a number of activities at Syracuse University, including presenting a radio program on WAER-FM 88.3 (i.e., Science on the Radio); writing a regular column for 55 Plus magazine; organizing and directing two science programs for students; giving tours of the Syracuse University campus; and a variety of other activities. My proudest achievement is having taught more than an estimated 45,000 students.

In my entire life, I had only two episodes with marijuana. On one occasion, I was strolling near the tennis courts on the South Campus of Syracuse University. I spotted an isolated plant growing outside the tennis court. It looked like a marijuana plant. I plucked a leaf and brought it home and used my references to identify the plant. It was, indeed, a leaf from a marijuana plant. I didn't know what to do with the leaf. Do I crush it and boil it, or roll it up and smoke it? I simply laughed and threw the leaf away.

On a second occasion, at a school reception, I came across a circle of graduate students. They were passing around a stubby cigarette and each student was taking a deep puff. I barged into the circle and said, "What's that? The last Lucky Strike cigarette?" My wife grabbed my arm and escorted me away from the circle. "Come here," she said, "I want to tell you something." Of course, the stubby cigarette was marijuana.

I never, voluntarily, went anywhere near other more dangerous and powerful drugs. Moreover, I didn't smoke. I once tried smoking a cigar. I took one puff, coughed and almost threw up. That was the end of cigars and smoking for me.

How about alcohol? I do have an occasional glass of wine or beer, but I really don't like to have alcoholic drinks. When I'm at a social event, I don't want to feel giddy and not know what I'm saying. I don't need alcohol to stimulate my speech. I talk enough without that stimulus, and I like to have coherent conversations with people.
Although I didn't acquire any of the usual addictions, I do have one major addiction, i.e., LIFE. I am addicted to doing as many positive things as I can, while I can. The theme that I would like to pass to readers is that" We learn from everything we do, and everything we do becomes part of who we are." Nobody can escape this addiction to LIFE, although some people try to supplement or replace it with alcohol and drugs. I realize how difficult it must be to be "hooked" on drugs. The drug world becomes reality and the real world is by-passed. There is no simple solution to the problem of drug addiction. I believe that the best solution is not to get started with drugs in the first place. Easier said than done for many. Indeed, there are many reasons why drug addicts become drug addicts. In this article, I will not attempt to talk drug addicts out of their addiction. It's impossible to cure addictions by simply trying to rationalize with a drug addict. Instead, I want to focus on positive thinking pathways to avoid getting addicted in the first place.

One way of avoiding addiction is to appreciate what life is really about and how special and sacred each life is. Every living thing is unique. Even identical twins, who have identical genotypes, are different. Each of us is the product of a genotype interacting with environments, and nobody can have the same environments. So, each of us has unique traits and each of us is special. This fact teaches us that someone can be taller, smarter, thinner, faster, etc. than someone else, but nobody is BETTER than anyone else. Each of us has unique, special traits and we should identify these traits and make the most of our positive ones. That's what formal education should be all about, i.e., helping individuals to identify and nurture their unique talents and helping them discover where they fit in life.

Superimposed on the brevity and uniqueness of each individual life, is our place in the universe. The earth is located in one spiral arm of a galaxy called the Milky Way that contains more than 100 billion stars and their planets. The universe contains countless numbers of galaxies with stars and planets. Most scientists believe that there is life elsewhere in the universe, although distances may make it virtually impossible to communicate with or identify such life. It is mind-boggling to realize that each of us is a unique grain of sand on a vast beach with many other sand grains. So, in one 
sense, one grain of sand may seem unimportant because there are so many others on the beach. In another sense, each grain of sand is unique and that fact gives each grain significance. Just thinking deeply about the importance of a single life may influence someone to abstain from taking drugs and, instead, focus on making the most of unique abilities and life. (c) (i) Creative Commons Attribution 4.0 International License

For possible submissions Click Here

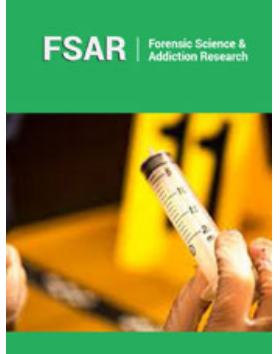

Forensic Science \& Addiction Research

\section{Benefits of Publishing with us}

- High-level peer review and editorial services

- Freely accessible online immediately upon publication

- Authors retain the copyright to their work

- Licensing it under a Creative Commons license

- Visibility through different online platforms 